\title{
Fetal Organ Volume Measurements by Three-dimensional Ultrasonography in Clinical Practice
}

\author{
Rodrigo Ruano
}

\begin{abstract}
The present manuscript reviews the main three-dimensional ultrasound (3DUS) methods that are clinically available to measure fetal organ volumes. Nowadays, it is possible to measure the volume of different organs (lungs, heart, liver, kidneys, adrenal glands and brain) using 3DUS. Those measurements are clinically useful to predict pulmonary hypoplasia, cardiac dysfunction and anomalies, fetal growth, renal function and prematurity as well as to predict adequate and normal neurodevelopment.
\end{abstract}

Keywords: Fetal adrenal gland, Fetal brain volume, Fetal heart volume, Fetal kidney volume, Fetal liver volume, Fetal lung volume, Fetal organ volumes, Three-dimensional ultrasonography.

How to cite this article: Ruano R. Fetal Organ Volume Measurements by Three-dimensional Ultrasonography in Clinical Practice. Donald School J Ultrasound Obstet Gynecol 2015;9(4):397-407.

\section{Source of support: Nil}

Conflict of interest: None

\section{INTRODUCTION}

The past three decades are remarkable for the impressive technological advance in ultrasound imaging methods. The three-dimensional ultrasonography (3DUS) represents one of these advances with the option to evaluate and measure fetal organ volumes in a three-dimensional image. Nowadays, new methods allow a volumetric measurement to be obtained faster and with more reproducibility. Particularly in maternal-fetal medicine, the possibility of evaluating the fetal organ volumes can impact in the perinatal management of the fetuses. In addition, new investigations have demonstrated that new methods can be used to estimate fetal weight in order to improve the diagnosis of intrauterine growth disorders. There are several studies that evaluated the impact of fetal

\section{Professor}

Department of Obstetrics and Gynecology, Baylor College of Medicine, Houston, Texas, USA

Corresponding Author: Rodrigo Ruano, Professor, Department of Obstetrics and Gynecology, Baylor College of Medicine, 6651 Main Street, Suite F, Houston, Texas, USA, e-mail: rodrigoruano@ hotmail.com organ volumes estimated by 3DUS on the clinical prenatal management of those fetuses. This article presents the different methods of assessing volumes by 3DUS and its potential clinical applications in actual fetal medicine.

\section{DIFFERENT METHODS TO CALCULATE THE VOLUME USING THE THREE-DIMENSIONAL ULTRASONOGRAPHY}

Basically, there are two simple and direct methods to assess the fetal organ volume using 3DUS approach. ${ }^{1}$ The first one, which is the oldest method, consists in adding together the areas of serial parallel slices of the studied organ. The 'technique of the parallel slices' is based on 'cutting' the organ in many slices and measuring the areas from one side to another with specific pre-established thickness (Fig. 1). The main disadvantage of this method is that it may be difficult for small organs with irregular shapes. ${ }^{1}$ Other limitations are described, such as the impossibility of repairing one incorrect area contouring.

More recently, a specific organ volume can be assessed by the rotational technique, which has become possible through the introduction of the 'virtual organ computer-aided analysis' (VOCAL $\left.{ }^{\mathrm{TM}}\right)$ imaging program, an extension of the 3D View TM (GE, Kretztechnik, Zipf, Austria). This method allows measuring the organ volume by fixing one axis and then serial contouring the organ surface after rotating the volumetric image (Fig. 2). The volumetric image can be rotating using different angles. This is faster than the first method, and has the great advantage over the other in allowing corrections and verifications on the three-dimensional image. Despite of many studies have been demonstrating similar values, variations and reproducibility (agreement) with these two methods, nowadays the 'rotational technique' is more employed and preferable due to its facilities. ${ }^{1}$

\section{MEDICAL APPLICATIONS OF THE THREE- DIMENSIONAL VOLUMETRIC EVALUATION}

\section{Fetal Weight Estimation}

One of the main objectives of the prenatal care is the correct detection of fetal growth abnormalities. The large number of methods published in this respect is a clearly evidence of the importance of fetal weight estimation 


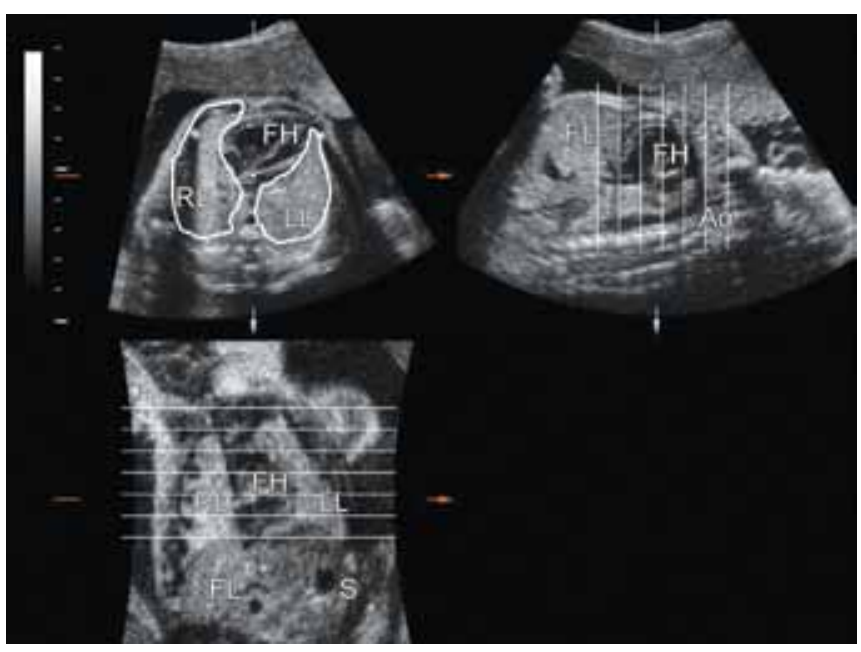

Fig. 1: Three-dimensional ultrasonographic parallel slices technique

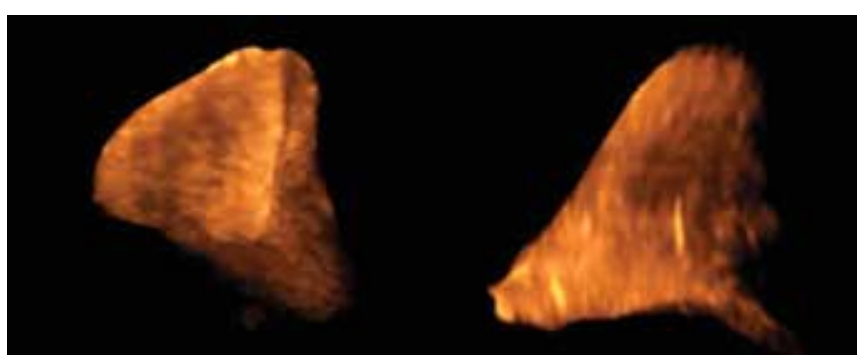

Fig. 2: Three-dimensional ultrasonographic rotational technique rendered imaging of right and left fetal lung volumes

during prenatal care. Both fetal macrosomia and growth restriction increase perinatal morbidity and mortality. Fetuses with growth restriction are at increased risk of hypoxia and perinatal deaths. On the other hand, macrosomic fetuses are associated with increased risk of cesarean-section, postpartum hemorrhage, and maternalfetal injuries. Macrosomic fetuses are generally associated with shoulder dystocia leading to clavicular fracture and brachial plexus injury.

Two-dimensional ultrasonography (2DUS) is applied routinely with this purpose. It estimates fetal weight indirectly by measuring defined segments of the body and then using specific mathematical equations, appropriate tables and integrated computer programs. The most frequently used fetal parameters are the biparietal diameter (BPD), head circumference (HC), abdominal circumference (AC) and femur length (Figs $3 \mathrm{~A}$ to $\mathrm{C}$ ). ${ }^{2-5}$ There are so many formulas for estimating fetal weight, which is clear evidence that none of those is accepted universally. All these formulas for fetal weight estimation have a mean error of 7 to $10 \%$, even in ideal ultrasound conditions.

The reason for the high error of these formulas may be the fact that none of these established equations takes the soft tissue thickness into account. It is known that fetal fat deposition represents approximately $90 \%$ of caloric accretion at term, and that neonatal fat mass constitutes 12 to $15 \%$ of birth weight. There have been many studies

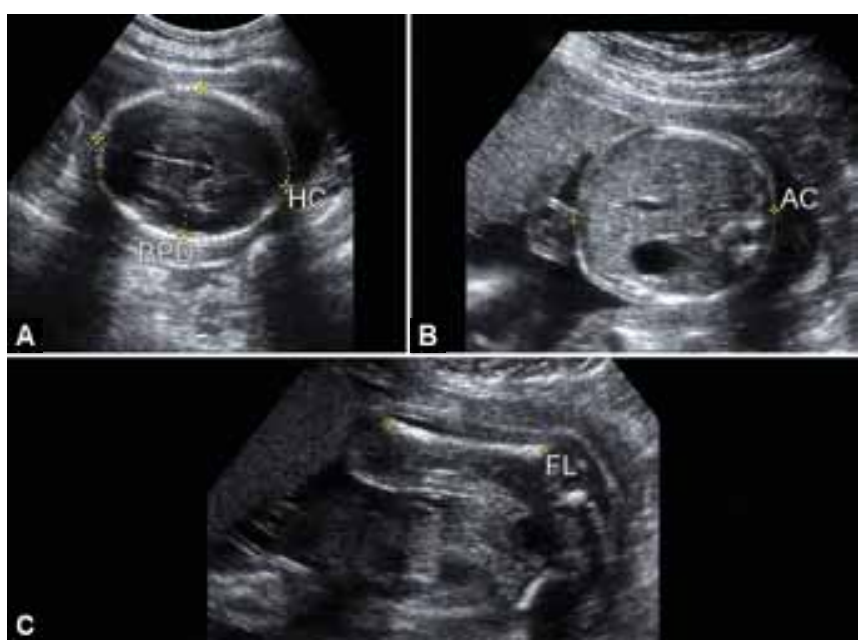

Figs $3 \mathbf{A}$ to $\mathrm{C}$ : Fetal parameters for fetal weight estimation: (A) Biparietal diameter and head circumference, (B) abdominal circumference and $(C)$ femur length

using different methods to take the soft-tissue content into account on 2DUS, especially by including the limb diameters, with varying results. ${ }^{6}$

Recently, with the advent of new volumetric methods using 3DUS technology, measurements of circumference and volume have become possible and reproducible through the three orthogonal sections of the specific fetal organ. Regarding the potential use for the estimation of fetal weight, the main interest becomes the possibility of measuring fetal limb diameters and volumes on these sections, which has the advantages of being more efficient and faster than the 2DUS technologies. ${ }^{6-9}$ In addition, these new methods allow incorporation of direct measurements of the fetal soft tissue in the equations to estimate fetal weight. The method used to measure the fetal limb volumes is called fractional limb volumes. ${ }^{6-9}$

The fractional limb volume is a method that the fetal soft tissue is evaluated from a central portion of the limb (arm and thigh) diaphysis (Figs 4 and 5). Transverse slices of the mid-limb are more likely to display the soft tissue borders. This technique reduces the measuring times and also improves the reproducibility of the method. Tables 1 and 2 present different mathematical equations and reference values of the limb volumes by gestational age.

\section{Fetal Organ Volume}

Three-dimensional ultrasound was first introduced during the 1980s, and has gained increasing acceptance in obstetrics as technological improvement. Its use has revolutionized the prenatal detection of fetal structural anomalies, growth aberrations, and multiple gestations. In recent years, 3DUS has undergone rapid advances, and continues to progress quickly. More recently, the estimation of fetal organ volumes is a promising application in maternal-fetal medicine. Different studies have 


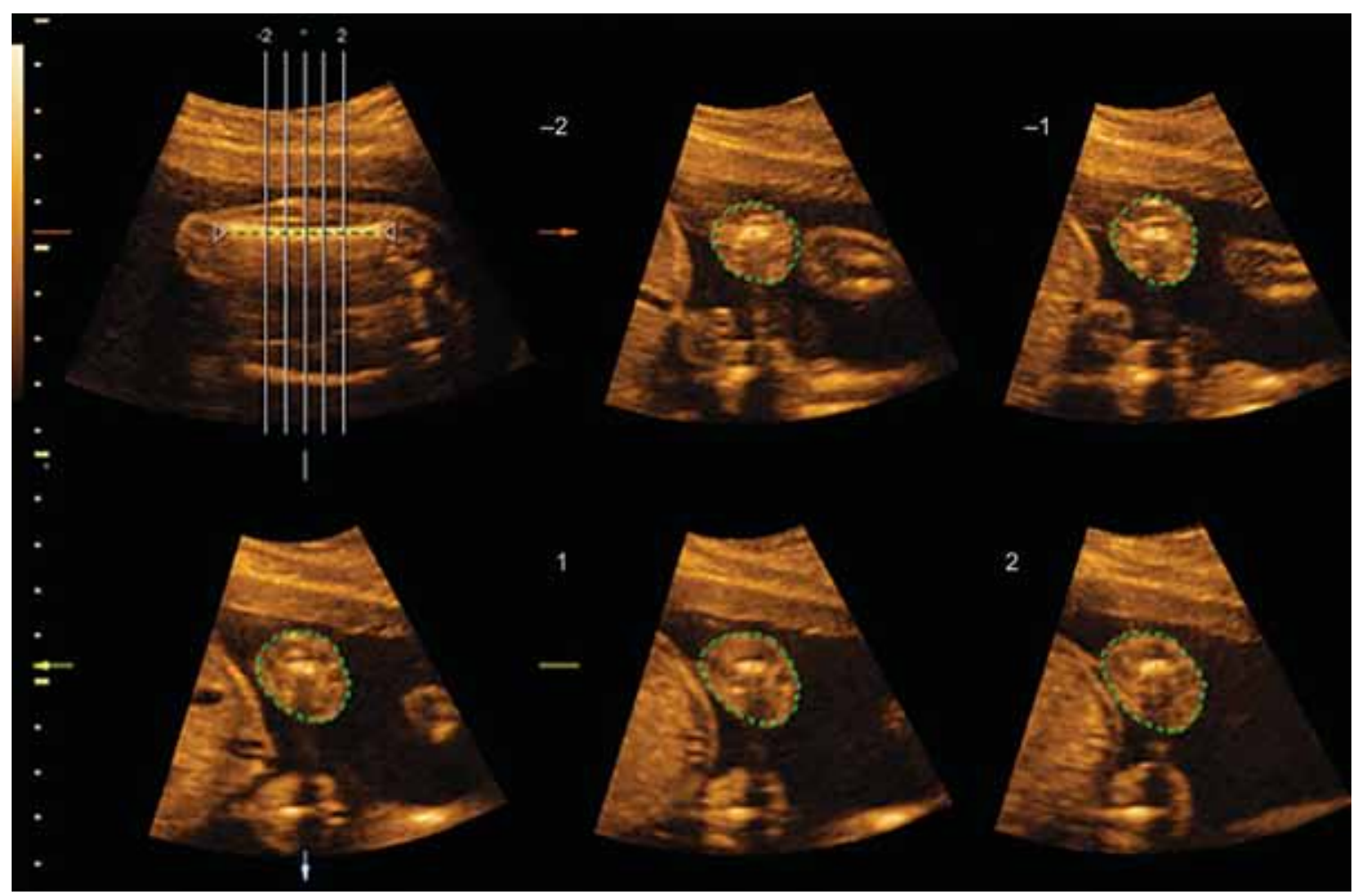

Fig. 4: Fractional thigh volume

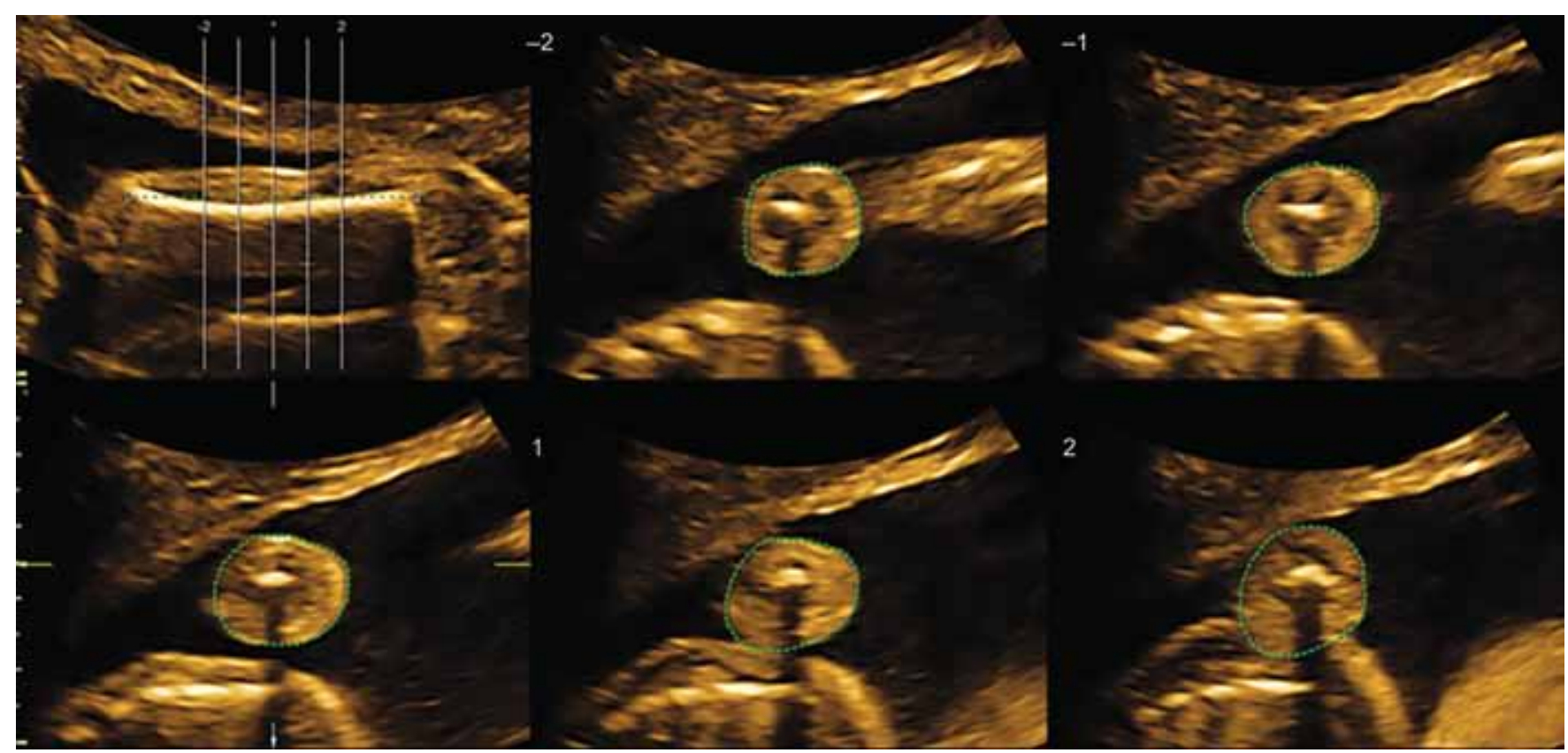

Fig. 5: Fractional arm volume

proposed the use of 3DUS to measure different fetal organ volumes (heart, liver, lung, brain, renal, adrenal gland and thymus). Unquestionably, 3DUS of fetal organs is gaining increasing importance in prenatal diagnosis, and will likely become an integral part of it in the near future.

The general essential prerequisites for measurement of a fetal organ volume are: first, acquisition of the volume with 'the organ of interest' facing the transducer; second, this acquisition must be in the absence of fetal movements and, third, accurate definition of the whole organ with good identification of its borders. Gestational age may interfere with the quality of the volumetric acquisition, and may limit posterior analysis of the 'organ of interest'. For example, lung volumes are more reproducible before 32 weeks, differently of the kidney volumes. Other important point is that acquisition and volumetric analysis depend on the amount of amniotic fluid and other organs shadows. 
Table 1: Fetal weight estimation formulae using 3DUS measurements

\begin{tabular}{ll}
\hline Author & Regression equation \\
\hline Lee et al & $\mathrm{FW}=20.95 \times$ Tvol $+113.571 \times \mathrm{AC}-2375.068$ \\
$2001^{6}$ & \\
Lee et al $^{7}$ & LogFW $=11.1372 \times \mathrm{BPD}^{2}-67.2281 \times \mathrm{BPD}+$ \\
2009 $^{7}$ & $1.2175 \times \mathrm{AC}^{2}-17.3004 \times \mathrm{AC}-0.0490 \times \mathrm{Tvol}^{2}+$ \\
& $25.3052 \times \mathrm{Tvol}^{2} 285.429$ \\
\hline
\end{tabular}

FW: Fetal weight; BPD: Biparietal diameter; HC: Head circumference; AC: Abdominal circumference; FL: Femur length; Tvol: Thigh volume; $A B D v o l$ : Abdominal volume

Table 2: Percentiles of fetal humerus volume $\left(\mathrm{cm}^{3}\right)$ estimated by 3DUS using the rotational technique (VOCAL ${ }^{\mathrm{TM}}$ ) in accordance to gestational age in weeks

\begin{tabular}{llll}
\hline & \multicolumn{3}{c}{ Fetal humerus volume $\left(\mathrm{cm}^{3}\right)$} \\
\cline { 2 - 4 }$G A$ & $10 \%$ & $50 \%$ & $90 \%$ \\
\hline 20 & 0.71 & 0.77 & 0.82 \\
22 & 0.86 & 0.97 & 1.07 \\
24 & 1.05 & 1.20 & 1.35 \\
26 & 1.28 & 1.48 & 1.67 \\
28 & 1.54 & 1.78 & 2.02 \\
30 & 1.84 & 2.12 & 2.41 \\
32 & 2.17 & 2.50 & 2.83 \\
34 & 2.54 & 2.91 & 3.29 \\
36 & 2.94 & 3.36 & 3.79 \\
38 & 3.38 & 3.85 & 4.32 \\
40 & 3.85 & 4.36 & 4.88 \\
\hline
\end{tabular}

Modified from Chang et al. Ultrasound in Medicine and Biology $2005^{9}$

\section{Fetal Lung Volume}

Clinically, fetal lung volume measurements can be useful to predict the severity of postnatal pulmonary hypoplasia more accurately in determined conditions, such as congenital diaphragmatic hernia, hyperechogenic lung lesions and oligohydramnios. Conventional 2DUS, which is used routinely in obstetrics, has proved to be insufficiently reliable to diagnose and predict prognosis of determinate congenital malformation, e.g. in fetuses at high risk for pulmonary hypoplasia. Recent studies have demonstrated the use of 3DUS in predicting pulmonary hypoplasia. ${ }^{10-21}$ This technology has the same advantages as 2DUS related to cost-effectiveness, feasible and speed of use and patient acceptability, but in addition, enables visualization of perpendicular planes simultaneously (multiplanar imaging) and acquisition of the entire organ volume.

Nowadays, studies demonstrate that both methods of measuring fetal lung volumes can be used, the parallel slices or the rotational technique. However, the rotational technique is preferable for small and irregular lungs, especially to evaluate lung volumes in congenital diaphragmatic hernia with better resolution (Figs 6A to D).
Assessing fetal lung volumes have been shown to be one of the best ways to predict neonatal prognosis in cases with congenital diaphragmatic hernia. ${ }^{10,12,14,18-21}$ The importance of predicting neonatal outcome in those fetuses is based on the possibility to select cases for antenatal interventions. Actually, fetuses with congenital diaphragmatic hernia presenting worse prognosis with high risk to develop severe pulmonary hypoplasia after birth may benefit from transitory tracheal occlusion during fetal life. ${ }^{22-30}$ The advantages of evaluating fetal lung volumes by 3DUS over assessing measurements on 2DUS are that the entire lung is considered in one image alone and that the lung ipsilateral to the diaphragmatic defect may be included in the analysis.

Predicting the severity of pulmonary hypoplasia may also be useful in fetuses with large hyperechogenic pulmonary lesions (adenomatoid malformation or pulmonary sequestration). For those fetuses, depending on the severity of the pulmonary hypoplasia, a few cases will benefit for early postnatal intervention such ex utero intrapartum treatment (EXIT) and extracorporeal membrane oxygenation (ECMO). ${ }^{31-33}$

More recent studies have also suggested that fetuses with very early and prolonged premature rupture of the membranes may also benefit from fetal tracheal occlusion. ${ }^{34-36}$ Fetal lung volumetric analysis may also be useful for the selection process in those cases.

There are so many reports on normal values and ranges of fetal lung volumes throughout gestational age. We have demonstrated that the right, left and total lung volumes vary from $5.37,4.66$ and $9.95 \mathrm{~cm}^{3}$ at 20 weeks to 46.6 , 37.34 , and $84.35 \mathrm{~cm}^{3}$ at 37 weeks, based on mathematical formulas: right lung volume $=\exp \{4.07 /[1+\exp (21.90-$ gestational age/5.44) $]\} ;$ left lung volume $=\exp \{3.82 /[1+$ $\exp (22.03$ - gestational age/5.17)]\}, and total lung volume $=$ $\exp \{4.72 /[1+\exp (20.30-$ gestational age $/ 6.05)]\}($ Table 3$) .{ }^{15}$

\section{Fetal Heart Volume}

Congenital heart disease is a leading cause of infant mortality in many countries, with an estimated incidence of about 3 to 8 per 1000 live births. Prenatal diagnosis of congenital heart diseases is responsible for a better planning of the perinatal management improving the postnatal care and outcomes.

Heart volume is a valuable parameter used in the evaluation of fetal heart condition, being mandatory for early detection of impending collapse of fetal circulation. Its accurate assessment becomes indispensable for prenatal diagnosis and management of fetal cardiac situations, such as in fetal high-output failure, hydrops fetalis, and many clinical-pathological conditions. The classical 

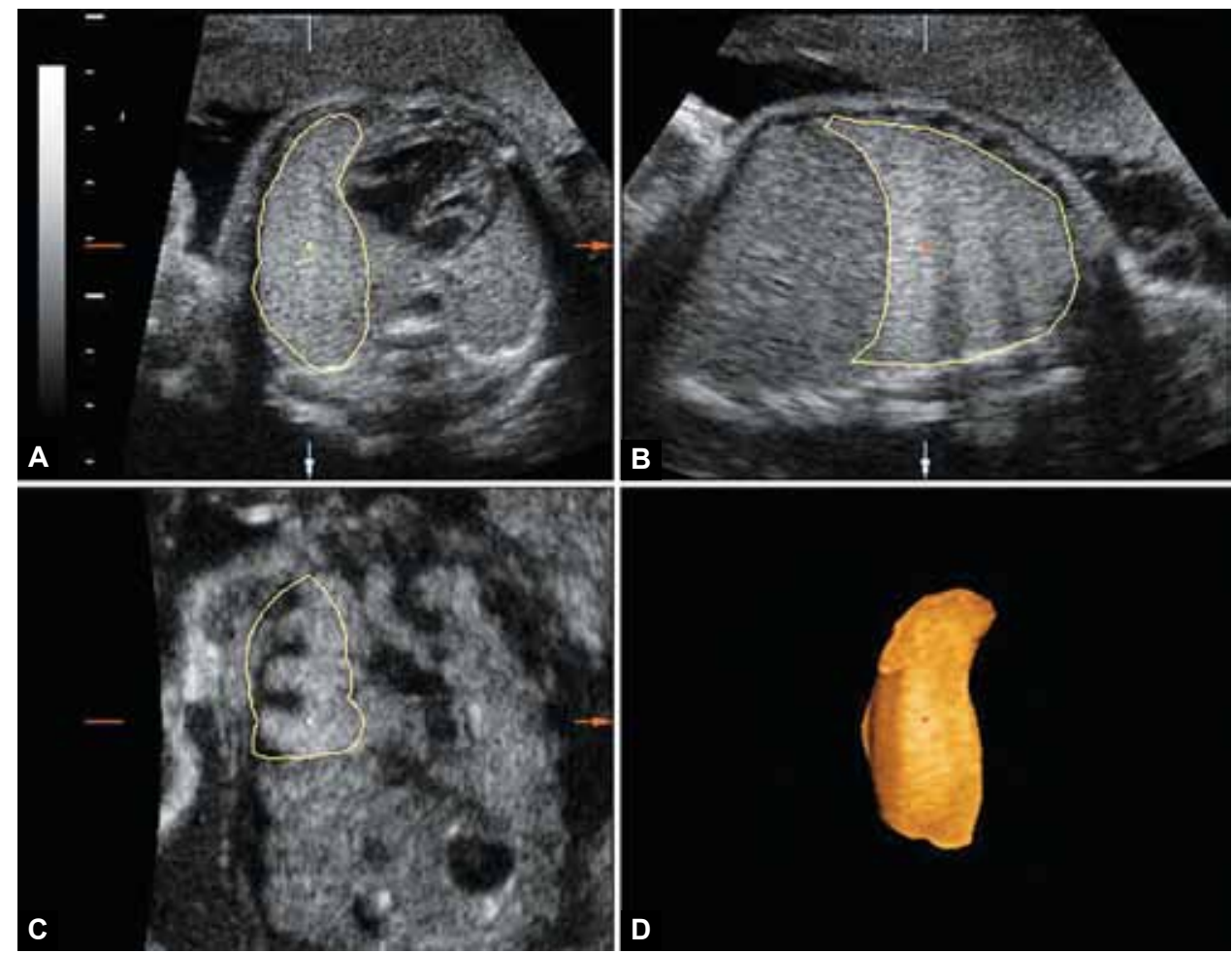

Figs 6A to D: Fetal lung volume: (A) Transverse section, (B) sagittal section, (C) coronal section and (D) rendered imaging

Table 3: Percentiles of fetal lung volume $\left(\mathrm{cm}^{3}\right)$ estimated by 3DUS using the rotational technique (VOCAL $\left.{ }^{\mathrm{TM}}\right)$ in accordance to gestational age in weeks

\begin{tabular}{|c|c|c|c|c|c|c|c|c|c|}
\hline \multirow[b]{3}{*}{$G A$} & \multicolumn{3}{|c|}{ Right fetal lung volume $\left(\mathrm{cm}^{3}\right)$} & \multicolumn{3}{|c|}{ Left fetal lung volume $\left(\mathrm{cm}^{3}\right)$} & \multicolumn{3}{|c|}{ Total fetal lung volume $\left(\mathrm{cm}^{3}\right)$} \\
\hline & \multicolumn{3}{|c|}{ Percentiles } & \multicolumn{3}{|c|}{ Percentiles } & \multicolumn{3}{|c|}{ Percentiles } \\
\hline & $10 \%$ & $50 \%$ & $90 \%$ & $10 \%$ & $50 \%$ & $90 \%$ & $10 \%$ & $50 \%$ & $90 \%$ \\
\hline 20 & 4.31 & 5.37 & 6.75 & 3.60 & 4.66 & 6.05 & 8.03 & 9.95 & 12.45 \\
\hline 22 & 6.23 & 7.77 & 9.68 & 5.21 & 6.69 & 8.58 & 11.59 & 14.66 & 18.28 \\
\hline 24 & 8.94 & 11.25 & 14.15 & 7.61 & 9.68 & 12.30 & 16.83 & 21.22 & 26.88 \\
\hline 26 & 12.81 & 15.96 & 20.09 & 10.28 & 13.60 & 17.12 & 23.66 & 29.70 & 37.52 \\
\hline 28 & 17.12 & 21.54 & 27.11 & 14.15 & 18.36 & 23.34 & 31.97 & 39.74 & 50.17 \\
\hline 30 & 21.98 & 27.66 & 34.47 & 18.73 & 23.34 & 29.96 & 40.73 & 50.63 & 63.99 \\
\hline 32 & 27.39 & 33.78 & 42.95 & 21.98 & 28.22 & 35.87 & 49.47 & 61.50 & 76.90 \\
\hline 34 & 32.14 & 39.25 & 49.90 & 24.78 & 32.46 & 41.68 & 57.84 & 71.62 & 92.03 \\
\hline 36 & 35.87 & 43.82 & 54.60 & 27.66 & 35.87 & 46.53 & 64.55 & 80.47 & 101.85 \\
\hline
\end{tabular}

Modified from Ruano, et al. Journal of Ultrasound in Medicine $2006^{15}$

method using 2DUS for assessing heart volume, which assumes that heart shape is spherical or elliptical is imprecise. However, before the advent of an appropriate noninvasive research tool, such as 3DUS, this was difficult to be evaluated in human fetuses.

Traditionally, fetal heart volume has been assessed by the equation: heart volume $=0.5233 \times \mathrm{H} 1 \times \mathrm{H} 2 \times \mathrm{H} 2$, where $\mathrm{H} 1$ is the largest longitudinal diameter of the fetal heart at the four-chamber view, and $\mathrm{H} 2$ is the largest transverse diameter at the same plane.

Fetal heart volumes can be evaluated by the rotational technique on 3DUS (Figs 7A to D). ${ }^{37,38}$ There have been a very few reports on normal values of fetal heart volume throughout gestational age. Fetal heart volume may vary from $0.63(0.40-0.86) \mathrm{cm}^{3}$ at 12 weeks to $26.60(16.40$ $36.80) \mathrm{cm}^{3}$ at 32 weeks (Table 4).

\section{Fetal Liver Volume}

Determination of fetal liver volume is very useful in assessing the status of fetal growth and nutrition. Fetuses with intrauterine growth restriction or macrosomia have different liver volumes. However, to measure human fetal liver in utero precisely and noninvasively is not an easy task. In the past, many studies have performed several attempts to indirectly assess liver size, using different parameters, such as $\mathrm{AC}$ and diameters (anteroposterior, transverse and cephalocaudal) using 2DUS, and then multiplied by a constant which had been obtained 


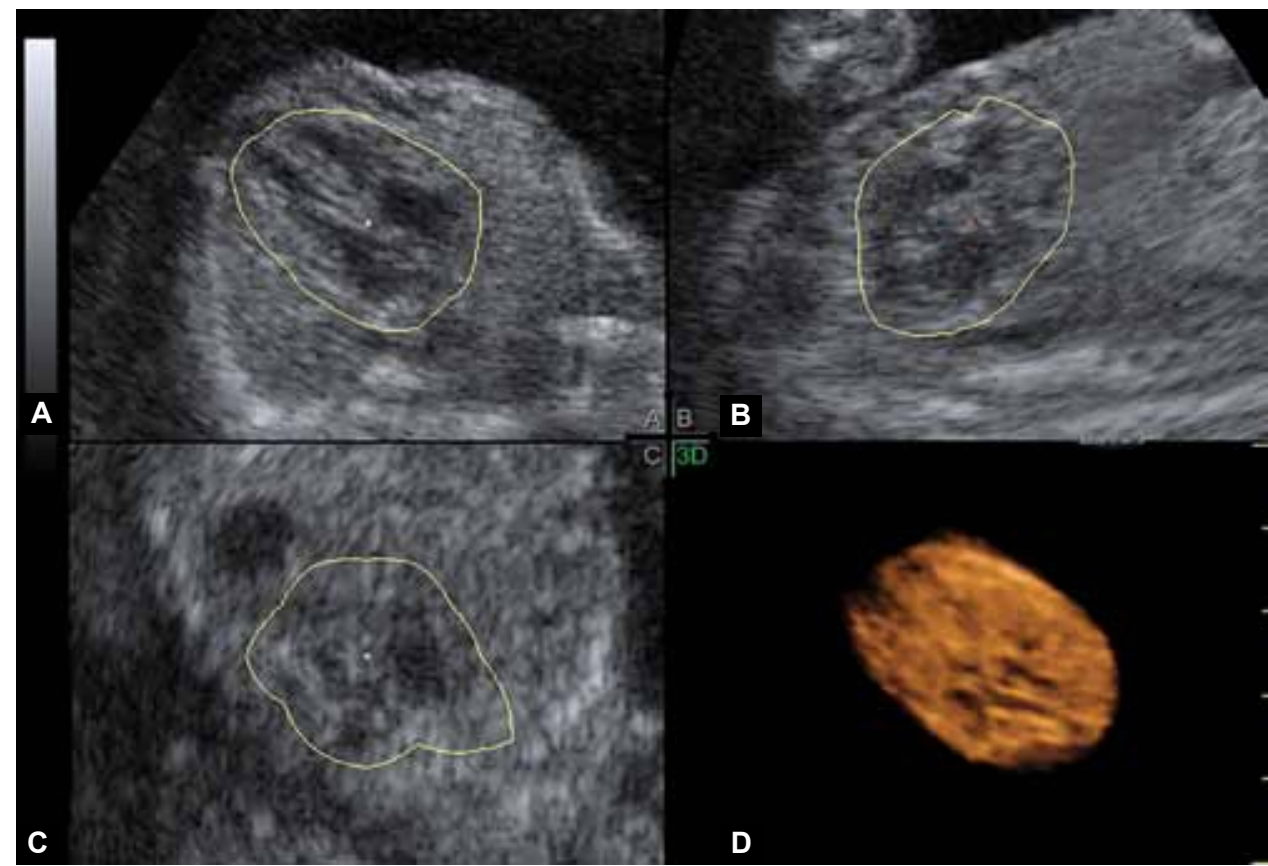

Figs 7A to D: Fetal heart volume: $(A)$ Transverse section, $(B)$ sagittal section, $(C)$ coronal section and (D) rendered imaging

from adult liver studies, to estimate fetal liver weight. Currently, fetal liver volume is measured using its longest diameter, which may be less reproducible. With the advent of 3DUS and the improvement of its technology, fetal liver volume assessment becomes possible, easier and more reproducible (Figs 8A to D) ${ }^{40-47}$ Besides, it has become an easy and noninvasive approach to obtain precise measurement of fetal liver volumes, and good correlation has been established between liver volume and other fetal growth parameters.

There have been very few studies reporting on normal ranges of fetal liver volumes assessed by 3DUS. Fetal liver volumes range from $11.73 \mathrm{~cm}^{3}$ at 20 weeks to $131.51 \mathrm{~cm}^{3}$ at 40 weeks (Table 5). ${ }^{42,47}$

\section{Fetal Renal Volume}

Renal diseases are not uncommon in fetal life, and some of them might be treatable or carry a better outcome if detected earlier. Evaluating fetal renal size may be a valuable tool in the detection and monitoring of renal conditions, including nephromegaly, hypoplasia and other anomalies. Besides, assessing fetal renal size may be useful to evaluate renal function. Konje et $\mathrm{al}^{48}$ demonstrated that fetal renin concentration is related to

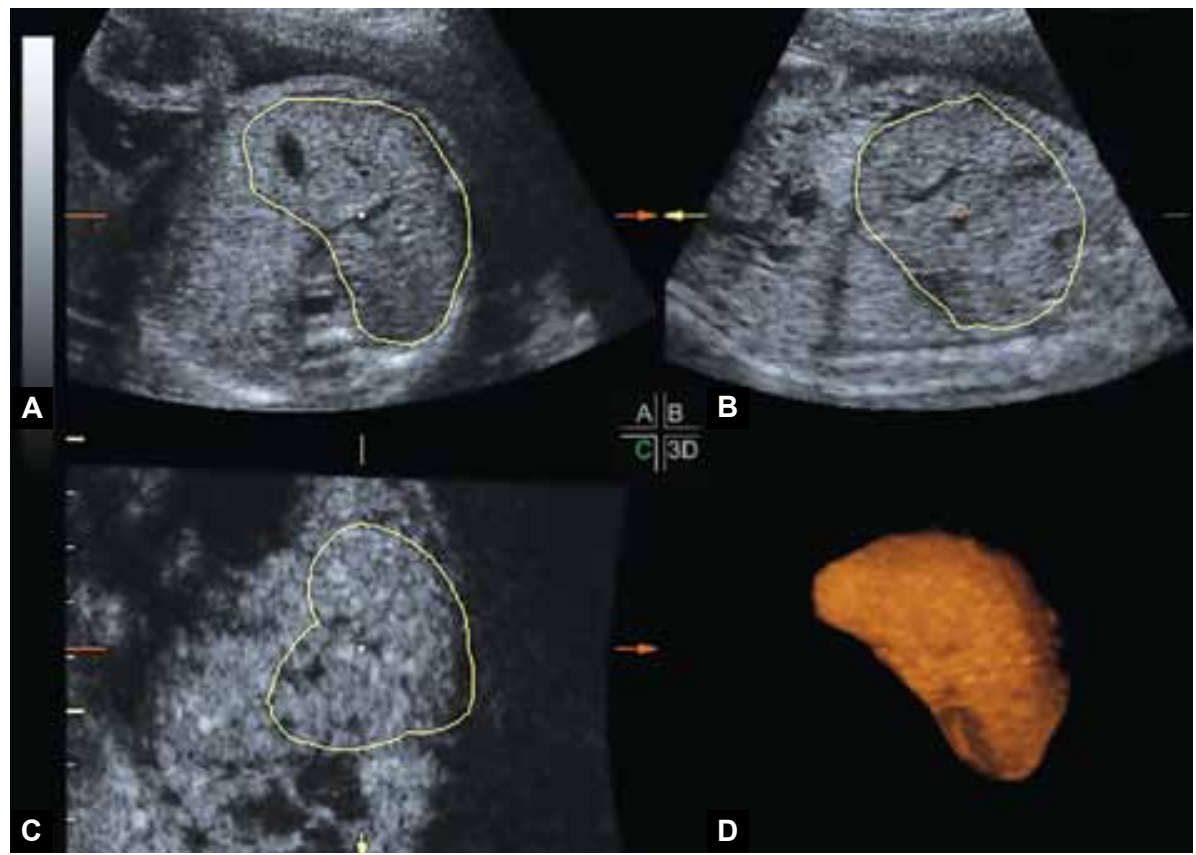

Figs 8A to D: Fetal liver volume: (A) Transverse section, (B) sagittal section, (C) coronal section and (D) rendered imaging 
Table 4: Percentiles of fetal heart volume $\left(\mathrm{cm}^{3}\right)$ estimated by 3DUS using the rotational technique $\left(\mathrm{VOCAL}^{\mathrm{TM}}\right)$ in accordance to gestational age in weeks

\begin{tabular}{llll}
\hline & \multicolumn{3}{c}{ Fetal heart volume $\left(\mathrm{cm}^{3}\right)$} \\
\cline { 2 - 4 }$G A$ & $2.50 \%$ & $50 \%$ & $97.50 \%$ \\
\hline 12 & 0.40 & 0.63 & 0.86 \\
14 & 0.17 & 0.53 & 0.88 \\
16 & 0.46 & 1.14 & 1.81 \\
18 & 1.24 & 2.42 & 3.61 \\
20 & 2.44 & 4.33 & 6.23 \\
22 & 4.04 & 6.83 & 9.62 \\
24 & 5.99 & 9.87 & 13.80 \\
26 & 8.24 & 13.40 & 18.60 \\
28 & 10.80 & 17.40 & 24.00 \\
30 & 13.50 & 21.80 & 30.10 \\
32 & 16.40 & 26.60 & 36.80 \\
\hline
\end{tabular}

Modified from Peralta, et al. Ultrasound in Obstetrics and Gynecology $2006^{39}$

fetal size. The classical way of measuring fetal renal size using 2DUS is not precise. With the application of 3DUS, it becomes feasible and more accurate by estimating fetal renal volumes (Figs 9A to D).

There have been very few reports on the distribution of fetal renal volumes throughout gestational age. Hsieh et $\mathrm{al}^{49}$ described good correlation between fetal renal volumes and gestational age, suggesting the following mathematical formulas: right fetal renal volume $=$ $0.4032 \times$ gestational age -6.2097 ; left fetal renal volume $=0.3954 \times$ gestational age -6.3068 . Yu et al ${ }^{50}$ reported the following mathematical formulas: right fetal renal volume $=0.74053 \times$ gestational week -13.318 ; left fetal renal volume $=0.76093 \times$ gestational age -13.421 .
Table 5: Percentiles of fetal liver volume $\left(\mathrm{cm}^{3}\right)$ estimated by 3DUS using the rotational technique (VOCAL ${ }^{\mathrm{TM}}$ ) in accordance to gestational age in weeks

\begin{tabular}{llll}
\hline & \multicolumn{3}{c}{ Fetal liver volume $\left(\mathrm{cm}^{3}\right)$} \\
\cline { 2 - 4 }$G A$ & $10 \%$ & $50 \%$ & $90 \%$ \\
\hline 20 & 5.05 & 11.84 & 18.63 \\
22 & 11.82 & 19.17 & 26.51 \\
24 & 17.00 & 24.90 & 32.80 \\
26 & 21.73 & 30.18 & 38.63 \\
28 & 27.18 & 36.13 & 45.13 \\
30 & 34.32 & 43.38 & 53.44 \\
32 & 44.46 & 54.57 & 64.69 \\
34 & 58.67 & 69.34 & 80.00 \\
36 & 78.08 & 83.30 & 100.53 \\
38 & 103.83 & 115.61 & 127.38 \\
40 & 137.05 & 149.38 & 161.71 \\
\hline
\end{tabular}

Modified from Chang et al. Ultrasound in Medicine and Biology $2003^{42}$

More recently, Yoshizaki et $\mathrm{a}^{51}$ reported the following mathematical formulas: expected right kidney volume $=$ $\exp [-1.01+(0.12 \times$ gestational age $)]$, and expected left kidney volume $=\exp [-0.90+(0.12 \times$ gestational age $)]$ (Table 6).

\section{Fetal Adrenal Gland Volume}

The fetal adrenal glands are important organs to fetal growth. In utero, the normal fetal adrenal glands can be scanned using 2DUS as hypoechogenic structures located immediately above the fetal kidneys bilaterally. Some pathologic conditions of fetal adrenal glands, such as adrenoblastomas or neuroblastomas, can be diagnosed on ultrasound examinations. These fetal adrenal tumors

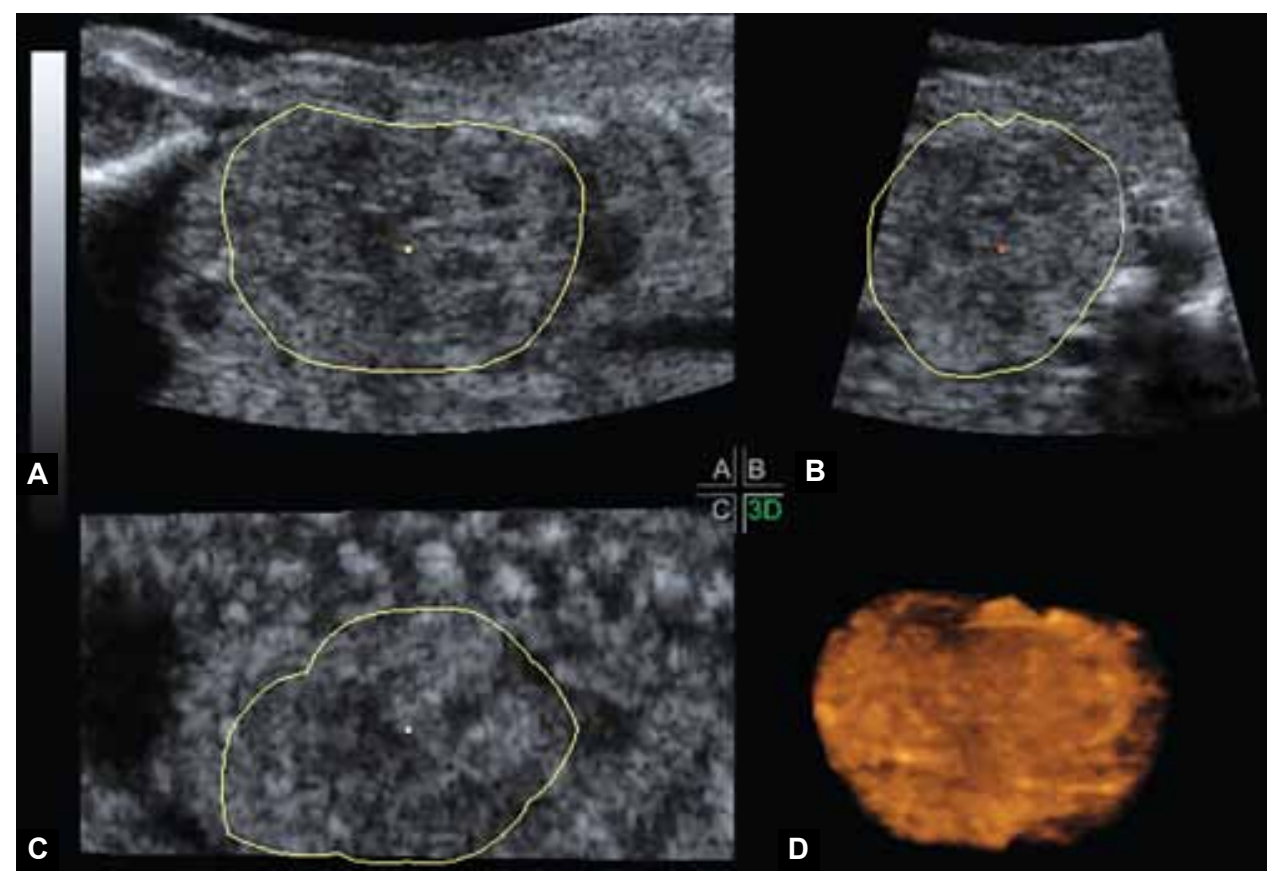

Figs 9A to D: Fetal renal volume: (A) Sagittal section, $(B)$ transverse section, $(C)$ coronal section and (D) rendered imaging 
Table 6: Percentiles of fetal renal volume $\left(\mathrm{cm}^{3}\right)$ estimated by 3DUS using the rotational technique $\left(\mathrm{VOCAL}^{\mathrm{TM}}\right)$ in accordance to gestational age in weeks

\begin{tabular}{|c|c|c|c|c|c|c|}
\hline \multirow[b]{3}{*}{$G A$} & \multirow{2}{*}{\multicolumn{3}{|c|}{$\begin{array}{c}\begin{array}{c}\text { Right fetal renal } \\
\text { volume }\left(\mathrm{cm}^{3}\right)\end{array} \\
\text { Percentiles }\end{array}$}} & \multirow{2}{*}{\multicolumn{3}{|c|}{$\begin{array}{c}\text { Left fetal renal } \\
\text { volume }\left(\mathrm{cm}^{3}\right) \\
\text { Percentiles }\end{array}$}} \\
\hline & & & & & & \\
\hline & $10 \%$ & $50 \%$ & $90 \%$ & $10 \%$ & $50 \%$ & $90 \%$ \\
\hline 20 & 2.4 & 4.0 & 6.9 & 2.4 & 4.2 & 7.4 \\
\hline 22 & 3.0 & 5.1 & 8.7 & 3.1 & 5.4 & 9.4 \\
\hline 24 & 3.9 & 6.5 & 11.1 & 3.9 & 6.8 & 11.8 \\
\hline 26 & 4.9 & 8.3 & 14.1 & 4.9 & 8.6 & 15.0 \\
\hline 28 & 6.3 & 10.6 & 18.0 & 6.2 & 10.8 & 18.9 \\
\hline 30 & 8.0 & 13.5 & 22.9 & 7.9 & 13.7 & 23.9 \\
\hline 32 & 10.1 & 17.2 & 29.1 & 9.9 & 17.3 & 30.2 \\
\hline 34 & 12.9 & 21.8 & 37.0 & 12.6 & 21.9 & 38.2 \\
\hline 36 & 14.1 & 27.8 & 47.1 & 15.9 & 27.7 & 48.4 \\
\hline 38 & 20.8 & 35.3 & 59.9 & 20.1 & 35.1 & 61.2 \\
\hline 40 & 26.5 & 45.0 & 76.2 & 25.4 & 44.3 & 77.3 \\
\hline
\end{tabular}

Modified from Yoshizaki, et al. J Ultrasound Med $2013^{51}$

may have abnormal sizes. Therefore, measuring this gland volume may be useful for the early diagnosis of this condition.

The irregular shape of fetal adrenal glands makes difficult to evaluate its volume using 2DUS. With the advent of 3DUS, using the rotational technique, it becomes feasible and noninvasive method to evaluate its volumes (Figs $10 \mathrm{~A}$ to D). ${ }^{52-57}$ Reference values may vary according to the following equation: adrenal gland volume $=$ $-0.2683 \times$ gestational age $+0.0082 \times(\text { gestational age })^{2}+$ 3.1927 (Table 7). ${ }^{52}$

Other interest in assessing fetal adrenal gland volumes can be related to a potential use in predicting labor, especially preterm labor. ${ }^{53,55}$ Several mechanisms have
Table 7: Percentiles of fetal adrenal gland volume $\left(\mathrm{cm}^{3}\right)$ estimated by $3 D U S$ using the rotational technique $\left(\mathrm{VOCAL}^{\mathrm{TM}}\right)$ in accordance to gestational age in weeks

\begin{tabular}{llll}
\hline & \multicolumn{3}{c}{ Fetal adrenal gland volume $\left(\mathrm{cm}^{3}\right)$} \\
\cline { 2 - 4 }$G A$ & $10 \%$ & $50 \%$ & $90 \%$ \\
\hline 22 & 0.86 & 1.24 & 1.63 \\
24 & 1.01 & 1.45 & 1.90 \\
26 & 1.22 & 1.73 & 2.25 \\
28 & 1.50 & 2.08 & 2.65 \\
30 & 1.85 & 2.49 & 3.13 \\
32 & 2.26 & 2.96 & 3.67 \\
34 & 2.74 & 3.51 & 4.27 \\
36 & 3.28 & 4.11 & 4.94 \\
38 & 3.89 & 4.78 & 5.68 \\
40 & 4.56 & 5.52 & 6.48 \\
\hline
\end{tabular}

Modified from Chang et al. Ultrasound in Medicine and Biology $2002^{52}$

been implicated in triggering preterm labor, like genetic predisposition, decidual hemorrhage, fetal stress and inflammation/infections. In most animal species, the fetal hypothalamic-pituitary-adrenal axis plays a special role in the initiation of parturition.

\section{Fetal Brain Volume}

Both fetal BPD and fetal HC are standard parameters in establishing normal and abnormal fetal biometry and growth. Fetal brain volume measurement in conjunction with fetal liver volume determination could provide insight into the nature of abnormal fetal growth. ${ }^{43} \mathrm{Up}$-todate, there have been few studies reporting on the use of 3DUS to assess fetal brain volume (Figs 11A to D). Fetal brain volumes vary from $53 \mathrm{~cm}^{3}$ at 20 weeks to $316 \mathrm{~cm}^{3}$

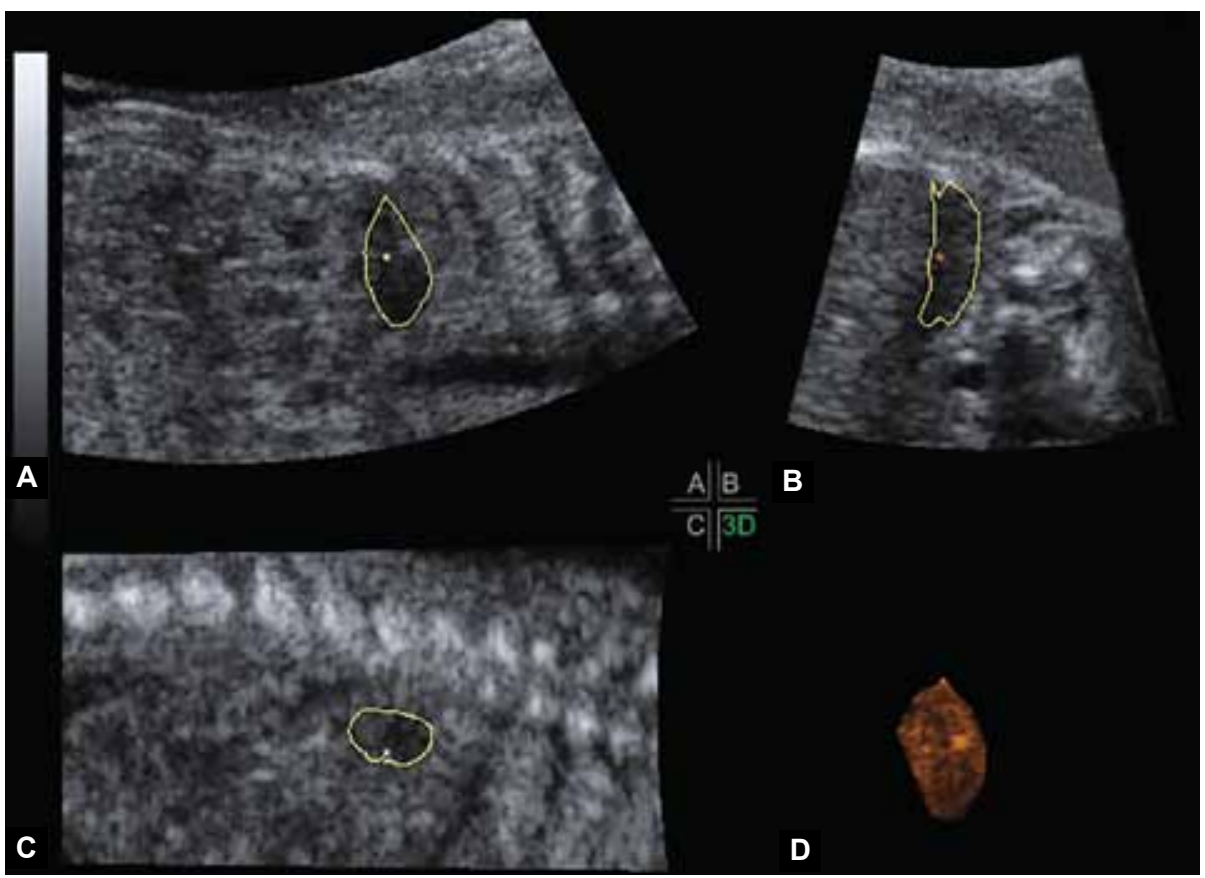

Figs $10 A$ to D: Fetal adrenal gland volume: $(A)$ Sagittal section, $(B)$ transverse section, $(C)$ coronal section and (D) rendered imaging 


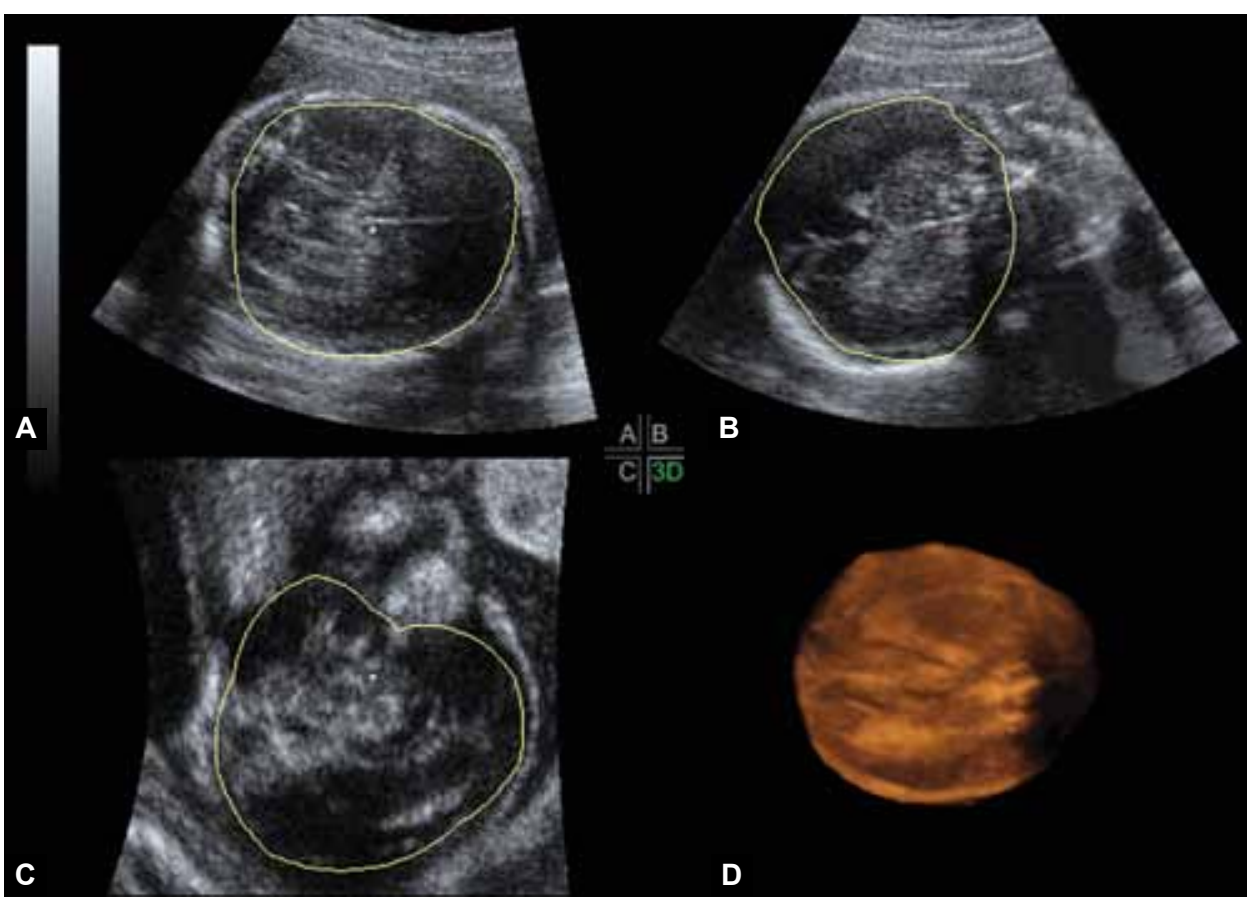

Figs 11A to D: Fetal brain volume: (A) Transverse section, (B) sagittal section, (C) coronal section and (D) rendered imaging

Table 8: Percentiles of fetal brain volume $\left(\mathrm{cm}^{3}\right)$ estimated by 3DUS using the rotational technique $\left(\mathrm{VOCAL}^{\mathrm{TM}}\right)$ in accordance to gestational age in weeks

\begin{tabular}{llll}
\hline & \multicolumn{3}{c}{ Fetal brain volume $\left(\mathrm{cm}^{3}\right)$} \\
\cline { 2 - 4 } & \multicolumn{3}{c}{ Percentiles } \\
\cline { 2 - 4 }$G A$ & $5 \%$ & $50 \%$ & $95 \%$ \\
\hline 20 & 38 & 53 & 71 \\
22 & 58 & 77 & 100 \\
24 & 82 & 116 & 133 \\
26 & 109 & 139 & 173 \\
28 & 140 & 177 & 218 \\
30 & 174 & 219 & 269 \\
32 & 211 & 265 & 326 \\
34 & 252 & 316 & 389 \\
\hline
\end{tabular}

Modified from Roelfsema et al. American Journal of Obstetrics and Gynecology $2004^{58}$

at 34 weeks according to the following equation: fetal brain volume $=0.75 \times$ gestational age -7.71 (Table 8$).{ }^{58}$

In addition to the entire fetal brain volume, it is possible to measure the fetal hippocampus, cerebellum, thalamus and ventricles. ${ }^{59-66}$ Recent studies have demonstrated that fetuses with particular diseases, such as congenital heart diseases have not only smaller brain, but reduced volumes of intracranial structures. ${ }^{67}$ Three-dimensional ultrasound is an important prenatal diagnostic tool in fetal neurosonography, which can be used to predict adequate neurodevelopment. ${ }^{68,69}$

\section{CONCLUSION}

Nowadays, it is possible to evaluate the fetal organ volumes using 3DUS technology. The main advantage of using 3DUS over 2DUS technology in measuring the organ volume is related to the fact that the first method permits evaluation of the entire organ instead of part of it. Using the rotational technique, the process of measuring the fetal organ volumes has become more feasible and reproducible. There is still a need to standardize and generalize the methods of measuring the fetal organ volumes. However, several clinical applications of 3DUS fetal organ measurements have been demonstrated.

\section{REFERENCES}

1. Ruano R. Recent advances in sonographic imaging of fetal thoracic structures. Expert Review of Medical Devices 2005;2(2):217-222.

2. Hadlock FP, Harrist RB, Martinez-Poyer J. In utero analysis of fetal growth: a sonographic weight standard. Radiology 1991;181(1):129-133.

3. Deter RL, Rossavik IK, Harrist RB, Hadlock FP. Mathematic modeling of fetal growth: development of individual growth curve standards. Obstet Gynecol 1986;68(2):156-161.

4. Hadlock FP, Deter RL, Harrist RB, Roecker E, Park SK. A date-independent predictor of intrauterine growth retardation: femur length/abdominal circumference ratio. Am J Roentgenol 1983;141(5):979-984.

5. Deter RL, Harrist RB, Hadlock FP, Poindexter AN. Longitudinal studies of fetal growth with the use of dynamic image ultrasonography. Am J Obstet Gynecol 1982;143(5):545-554.

6. Lee W, Deter RL, Ebersole JD, Huang R, Blanckaert K, Romero R. Birth weight prediction by three-dimensional ultrasonography: fractional limb volume. J Ultrasound Med. 2001;20(12):1283-1292.

7. Lee W, Balasubramaniam M, Deter RL, Yeo L, Hassan SS, Gotsch F, Kusanovic JP, Goncalves LF, Romero R. New fetal weight estimation models using fractional limb volume. Ultrasound Obstet Gynecol 2009;34(5):556-565.

8. Lee W, Deter R, Sangi-Haghpeykar H, Yeo L, Romero R. Prospective validation of fetal weight estimation using fractional limb volume. Ultrasound Obstet Gynecol 2013;41(2):198-203. 
9. Chang $\mathrm{CH}, \mathrm{Yu} \mathrm{CH}, \mathrm{Ko} \mathrm{HC}$, Chen $\mathrm{CL}$, Chang FM. Fetal upper arm volume in predicting intrauterine growth restriction: a three-dimensional ultrasound study. Ultrasound Med Biol 2005;31(11):1435-1439.

10. Ruano R, Benachi A, Martinovic J, Grebille AG, Aubry MC, Dumez Y, Dommergues M. Can three-dimensional ultrasound be used for the assessment of the fetal lung volume in cases of congenital diaphragmatic hernia? Fetal Diagnosis and Therapy 2004;19(1):87-91.

11. Sabogal JC, Becker E, Bega G, Komwilaisak R, Berghella V, Weiner S, Tolosa J. Reproducibility of fetal lung volume measurements with 3-dimensional ultrasonography. J Ultrasound Med 2004;23(3):347-352.

12. Ruano R, Martinovic J, Dommergues M, Aubry MC, Dumez Y, Benachi A. Accuracy of fetal lung volume assessed by threedimensional sonography. Ultrasound Obstet Gynecol 2005; 26(7):725-730.

13. Gerards FA, Engels MA, Twisk JW, van Vugt JM. Normal fetal lung volume measured with three-dimensional ultrasound. Ultrasound Obstet Gynecol. 2006;27(2):134-144.

14. Ruano R, Aubry MC, Barthe B, Mitanchez D, Dumez Y, Benachi A. Quantitative analysis of fetal pulmonary vasculature by 3-dimensional power Doppler ultrasonography in isolated congenital diaphragmatic hernia. Am J Obstetrics Gynecol 2006;195(6):1720-1728.

15. Ruano R, Joubin L, Aubry MC, Thalabard JC, Dommergues M, Dumez Y, Benachi A. A nomogram of fetal lung volumes estimated by 3-dimensional ultrasonography using the rotational technique (virtual organ computer-aided analysis). Ultrasound Med 2006;25(6):701-709.

16. Gerards FA, Twisk JW, Bakker M, Barkhof F, van Vugt JM. Fetal lung volume: three-dimensional ultrasonography compared with magnetic resonance imaging. Ultrasound Obstet Gynecol 2007;29(5):533-536.

17. Hata T, Kuno A, Dai SY, Inubashiri E, Hanaoka U, Kanenishi K, Yamashiro C, Tanaka H, Yanagihara T. Three-dimensional sonographic volume measurement of the fetal lung. J Obstet Gynaecol Res 2007;33(6):793-798.

18. Ruano R, Aubry MC, Barthe B, Dumez Y, Zugaib M, Benachi A. Ipsilateral lung volumes assessed by three-dimensional ultrasonography in fetuses with isolated congenital diaphragmatic hernia. Fetal Diagnosis and Therapy 2008;24(4):389-394.

19. Kehl S, Eckert S, Sutterlin M, Neff KW, Siemer J. Influence of different rotation angles in assessment of lung volumes by 3-dimensional sonography in comparison to magnetic resonance imaging in healthy fetuses. J Ultrasound Med 2011;30(6):819-825.

20. Prendergast M, Rafferty GF, Davenport M, Persico N, Jani J, Nicolaides K, Greenough A. Three-dimensional ultrasound fetal lung volumes and infant respiratory outcome: a prospective observational study. BJOG: an International Journal of Obstetrics and Gynaecology 2011;118(5):608-614.

21. Kehl S, Becker L, Eckert S, Weiss C, Schaible T, Neff KW, Siemer J, Sutterlin M. Prediction of mortality and the need for neonatal extracorporeal membrane oxygenation therapy by 3-dimensional sonography and magnetic resonance imaging in fetuses with congenital diaphragmatic hernias. J Ultrasound Med 2013;32(6):981-988.

22. Deprest J, Gratacos E, Nicolaides KH. Fetoscopic tracheal occlusion (FETO) for severe congenital diaphragmatic hernia: evolution of a technique and preliminary results. Ultrasound Obstet Gynecol 2004;24(2):121-126.

23. Deprest JA, Hyett JA, Flake AW, Nicolaides K, Gratacos E. Current controversies in prenatal diagnosis 4: Should fetal surgery be done in all cases of severe diaphragmatic hernia? Prenat Diagn 2009;29(1):15-19.
24. Deprest JA, Nicolaides K, Gratacos E. Fetal surgery for congenital diaphragmatic hernia is back from never gone. Fetal Diagn Ther 2011;29(1):6-17.

25. Ruano R, Duarte SA, Pimenta EJ, Takashi E, da Silva MM, Tannuri U, Zugaib M. Comparison between fetal endoscopic tracheal occlusion using a $1.0 \mathrm{~mm}$ fetoscope and prenatal expectant management in severe congenital diaphragmatic hernia. Fetal Diagn Ther 2011;29(1):64-70.

26. Deprest J, De Coppi P. Antenatal management of isolated congenital diaphragmatic hernia today and tomorrow: ongoing collaborative research and development. J Pediatric Surg Lecture. J Pediatr Surg 2012;47(2):282-290.

27. Ruano R, da Silva MM, Campos JA, Papanna R, Moise K, Jr, Tannuri U, Zugaib M. Fetal pulmonary response after fetoscopic tracheal occlusion for severe isolated congenital diaphragmatic hernia. Obstet gynecol 2012;119(1):93-101.

28. Ruano R, Yoshisaki CT, da Silva MM, Ceccon ME, Grasi MS, Tannuri U, Zugaib M. A randomized controlled trial of fetal endoscopic tracheal occlusion versus postnatal management of severe isolated congenital diaphragmatic hernia. Ultrasound Obstet Gynecol 2012;39(1):20-27.

29. Done E, Gratacos E, Nicolaides KH, Allegaert K, Valencia C, Castanon M, Martinez JM, Jani J, Van Mieghem T, Greenough A, et al. Predictors of neonatal morbidity in fetuses with severe isolated congenital diaphragmatic hernia undergoing fetoscopic tracheal occlusion. Ultrasound Obstet and Gynecol 2013;42(1):77-83.

30. Ruano R, Peiro JL, da Silva MM, Campos JA, Carreras E, Tannuri U, Zugaib M. Early fetoscopic tracheal occlusion for extremely severe pulmonary hypoplasia in human isolated congenital diaphragmatic hernia: preliminary results. Ultrasound Obstet Gynecol 2013.

31. Keller TM, Rake A, Michel SC, Seifert B, Wisser J, Marincek B, Kubik-Huch RA. MR assessment of fetal lung development using lung volumes and signal intensities. Eur Radiol 2004;14(6):984-989.

32. Matsushita $M$, Ishii $K$, Tamura $M$, Takahashi $Y$, Kamura $T$, Takakuwa K, Tanaka K. Perinatal magnetic resonance fetal lung volumetry and fetal lung-to-liver signal intensity ratio for predicting short outcome in isolated congenital diaphragmatic hernia and cystic adenomatoid malformation of the lung. J Obstet Gynaecol Res 2008;34(2):162-167.

33. Rypens F, Metens T, Rocourt N, Sonigo P, Brunelle F, Quere MP, Guibaud L, Maugey-Laulom B, Durand C, Avni FE, et al. Fetal lung volume: estimation at MR imaging-initial results. Radiology 2001;219(1):236-241.

34. Kohl T, Geipel A, Tchatcheva K, Stressig R, Willinek WA, Gembruch U, Muller A. Life-saving effects of fetal tracheal occlusion on pulmonary hypoplasia from preterm premature rupture of membranes. Obstet Gynecol 2009;113(2 Pt 2):480-483.

35. Barth WH, Jr. Fetoscopic tracheal occlusion for previable rupture of the membranes: recklessness or heroic medical innovation? Obstet Gynecol 2009;113(2 Pt 2):473-475.

36. Kohl T, Muller A, Franz A, Heep A, Willinek WA, Bartmann P, Gembruch U. Temporary fetoscopic tracheal balloon occlusion enhanced by hyperoncotic lung distension: is there a role in the treatment of fetal pulmonary hypoplasia from early preterm premature rupture of membranes? Fetal Diagn Ther 2007;22(6):462-465.

37. Chang FM, Hsu KF, Ko HC, Yao BL, Chang $\mathrm{CH}, \mathrm{Yu} \mathrm{CH}$, Liang RI, Chen HY. Fetal heart volume assessment by three-dimensional ultrasound. Ultrasound Obstet Gynecol 1997;9(1):42-48.

38. Herberg U, Luck S, Steinweg B, Brand M, Knies R, Geipel A, Trier HG, Breuer J. Volumetry of fetal hearts using 3D real- 
time matrix echocardiography-in vitro validation experiments and 3D echocardiographic studies in fetuses. Ultraschall Med 2011;32(1):46-53.

39. Peralta CF, Cavoretto P, Csapo B, Falcon O, Nicolaides KH. Lung and heart volumes by three-dimensional ultrasound in normal fetuses at 12-32 weeks gestation. Ultrasound Obstet Gynecol 2006;27(2):128-133.

40. Chang $\mathrm{CH}, \mathrm{Yu} \mathrm{CH}, \mathrm{Ko} \mathrm{HC}$, Chen CL, Chang FM. Predicting fetal growth restriction with liver volume by threedimensional ultrasound: efficacy evaluation. Ultrasound Med Biol 2006;32(1):13-17.

41. Boito SM, Struijk PC, Ursem NT, Stijnen T, Wladimiroff JW. Assessment of fetal liver volume and umbilical venous volume flow in pregnancies complicated by insulin-dependent diabetes mellitus. BJOG : an International Journal of Obstetrics and Gynaecology 2003;110(11):1007-1013.

42. Chang $\mathrm{CH}, \mathrm{Yu} \mathrm{CH}$, Chang FM, Ko HC, Chen HY. The assessment of normal fetal liver volume by three-dimensional ultrasound. Ultrasound Med Biol 2003;29(8):1123-1129.

43. Boito S, Struijk PC, Ursem NT, Fedele L, Wladimiroff JW. Fetal brain/liver volume ratio and umbilical volume flow parameters relative to normal and abnormal human development. Ultrasound Obstet Gynecol 2003;21(3):256-261.

44. Boito SM, Laudy JA, Struijk PC, Stijnen T, Wladimiroff JW. Three-dimensional US assessment of hepatic volume, head circumference, and abdominal circumference in healthy and growth-restricted fetuses. Radiology 2002;223(3):661-665.

45. Kuno A, Hayashi Y, Akiyama M, Yamashiro C, Tanaka H, Yanagihara T, Hata T. Three-dimensional sonographic measurement of liver volume in the small-for-gestational-age fetus. J Ultrasound Med 2002;21(4):361-366.

46. Laudy JA, Janssen MM, Struyk PC, Stijnen T, Wallenburg HC, Wladimiroff JW. Fetal liver volume measurement by three-dimensional ultrasonography: a preliminary study. Ultrasound Obstet Gynecol 1998;12(2):93-96.

47. Chang FM, Hsu KF, Ko HC, Yao BL, Chang CH, Yu CH, Chen HY. Three-dimensional ultrasound assessment of fetal liver volume in normal pregnancy: a comparison of reproducibility with two-dimensional ultrasound and a search for a volume constant. Ultrasound Med Biol 1997;23(3):381-389.

48. Konje JC, Bell SC, Morton JJ, de Chazal R, Taylor DJ. Human fetal kidney morphometry during gestation and the relationship between weight, kidney morphometry and plasma active renin concentration at birth. Clin Sci (Lond). 1996;91(2):169-175.

49. Hsieh YY, Chang CC, Lee CC, Tsai HD. Fetal renal volume assessment by three-dimensional ultrasonography. Am J Obstet Gynecol 2000;182(2):377-379.

50. Yu C, Chang C, Chang F, Ko H, Chen H. Fetal renal volume in normal gestation: a three-dimensional ultrasound study. Ultrasound Med Biol 2000;26(8):1253-1256.

51. Yoshizaki CT, Francisco RP, de Pinho JC, Ruano R, Zugaib M. Renal volumes measured by 3-dimensional sonography in healthy fetuses from 20 to 40 weeks. J Ultrasound Med 2013;32(3):421-427.

52. Chang $\mathrm{CH}, \mathrm{YuCH}$, Chang FM, Ko HC, Chen HY. Assessment of fetal adrenal gland volume using three-dimensional ultrasound. Ultrasound Med Biol 2002;28(11-12):1383-1387.

53. Buhimschi CS, Turan OM, Funai EF, Azpurua H, Bahtiyar MO, Turan S, Zhao G, Dulay A, Bhandari V, Copel JA, et al. Fetal adrenal gland volume and cortisol/dehydroepiandrosterone sulfate ratio in inflammation-associated preterm birth. Obstet Gynecol 2008;111(3):715-722.

54. Gindes L, Pretorius DH, Romine LE, Kfir M, D'Agostini D, Hull A, Achiron R. Three-dimensional ultrasonographic depiction of fetal abdominal blood vessels. J Ultrasound Med 2009;28(8):977-988.

55. Turan OM, Turan S, Buhimschi IA, Funai EF, Campbell KH, BahtiyarOM,Harman CR, CopelJA, Baschat AA, BuhimschiCS. Comparative analysis of $2 \mathrm{D}$ versus $3 \mathrm{D}$ ultrasound estimation of the fetal adrenal gland volume and prediction of preterm birth. Am J Perinatol 2012;29(9):673-680.

56. Chang $\mathrm{CH}, \mathrm{Yu} \mathrm{CH}$, Chang FM, Ko HC, Chen HY. Assessment of fetal adrenal gland volume using three-dimensional ultrasound. Ultrasound in Med Bio 2002;28(11-12):1383-1387.

57. Hoffman Sage Y, Lee L, Thomas AM, Benson CB, Shipp TD. Fetal adrenal gland volume and preterm birth: a prospective third-trimester screening evaluation. J Maternal-Fetal and Neonatal Med 2015:1-4.

58. Roelfsema NM, Hop WC, Boito SM, Wladimiroff JW. Threedimensional sonographic measurement of normal fetal brain volume during the second half of pregnancy. Am J Obstet Gynecol 2004;190(1):275-280.

59. Chang $\mathrm{CH}, \mathrm{Yu} \mathrm{CH}$, Chang FM, Ko HC, Chen HY. The assessment of normal fetal brain volume by 3-D ultrasound. Ultrasound Med Biol 2003;29(9):1267-1272.

60. Bornstein E, Monteagudo A, Santos R, Keeler SM, TimorTritsch IE. A systematic technique using 3-dimensional ultrasound provides a simple and reproducible mode to evaluate the corpus callosum. Am J Obstet Gynecol 2010; 202(2):201e1-5.

61. Bornstein E, Monteagudo A, Santos R, Strock I, Tsymbal T, Lenchner E, Timor-Tritsch IE. Basic as well as detailed neurosonograms can be performed by offline analysis of three-dimensional fetal brain volumes. Ultrasound Obstet Gynecol 2010;36(1):20-25.

62. Gindes L, Weissmann-Brenner A, Weisz B, Zajicek M, Geffen KT, Achiron R. Identification of the fetal hippocampus and fornix and role of 3-dimensional sonography. J Ultrasound Med 2011;30(12):1613-1618.

63. Rizzo G, Pietrolucci ME, Capponi A, Arduini D. Assessment of corpus callosum biometric measurements at 18 to 32 weeks gestation by 3-dimensional sonography. J Ultrasound Med 2011;30(1):47-53.

64. Scheier M, Lachmann R, Petros M, Nicolaides KH. Threedimensional sonography of the posterior fossa in fetuses with open spina bifida at 11-13 weeks gestation. Ultrasound Obstetrics Gynecol 2011;38(6):625-629.

65. Rizzo G, Pietrolucci ME, Mammarella S, Dijmeli E, Bosi C, Arduini D. Assessment of cerebellar vermis biometry at 18 to 32 weeks of gestation by three-dimensional ultrasound examination. J Maternal-Fetal and Neonatal Med 2012;25(5):519-522.

66. Scott JA, Hamzelou KS, Rajagopalan V, Habas PA, Kim K, Barkovich AJ, Glenn OA, Studholme C. 3D morphometric analysis of human fetal cerebellar development. Cerebellum 2012;11(3):761-770.

67. Zeng S, Zhou QC, Zhou JW, Li M, Long C, Peng QH. Volume of intracranial structures on three-dimensional ultrasound in fetuses with congenital heart disease. Ultrasound Obstetrics Gynecol 2015;46(2):174-181.

68. Monteagudo A, Timor-Tritsch IE, Mayberry P. Three-dimensional transvaginal neurosonography of the fetal brain: navigating in the volume scan. Ultrasound Obstetrics Gynecol 2000;16(4):307-313.

69. Kuklisova-Murgasova M, Cifor A, Napolitano R, Papageorghiou A, Quaghebeur G, Rutherford MA, Hajnal JV, Noble JA, Schnabel JA. Registration of 3D fetal neurosonography and MRI. Medical Image Analysis 2013;17(8):1137-1150. 